\title{
FLEXIBLE MANUFACTURING SYSTEMS (FMS): A REVIEW
}

\author{
MANU. ${ }^{1}$, VIJAY KUMAR. $M^{2}$, NAGESH. H $^{3}$, JAGADEESH. $\mathrm{D}^{\mathbf{4}}$ \& GOWTHAM. M. $\mathrm{B}^{\mathbf{5}}$ \\ ${ }^{1,3}$ Assistant Professor, Mechanical Engineering Department, SJCIT, Chickballapur, Karnataka, India \\ ${ }^{2}$ Associate Professor, Department of IEM, JSSATE, Bengaluru, Karnataka, India \\ ${ }^{4,5}$ Student, 7th Semester Mechanical Engineering Department, S. J. C. I. T, Chickballapur, Karnataka, India
}

\begin{abstract}
Today's manufacturing environment demands for manufacturing performance to accomplish the task in the stipulated time interval. Hence, flexibility of the manufacturing systems becomes an important issue which has led to the development of Flexible manufacturing systems (FMS). This unique production system encapsulates various components such as a computer programmed machine tools, automated material handling systems, robots, and Inspection and self diagnostic facilities into a single production system. FMSs are recognized by the replacement of computer control set up of the hard mechanization generally found in exchange lines. The high venture required for a FMS and the capability of FMS as a key aggressive device makes it alluring to take part in exploring around there. This paper presents a review related to the various aspects of FMS. Articles underscoring numerous methodological points of view are basically audited. It is believed that this article results in bridging the gaps between the various crucial aspects required for its implementation.

KEYWORDS: Flexible Manufacturing Systems (FMS), Scheduling; Mathematical Model, Tools \& Route Path
\end{abstract}

Received: Dec 20, 2017; Accepted: Jan 10, 2018; Published: Mar 01, 2018; Paper Id.: IJMPERDAPR201836

\section{INTRODUCTION}

The new challenges in the contending business can be encountered by modern manufacturing systems. The introduction of Flexible manufacturing System (FMS) has paved the way for the manufacturing industries to improve their performance together with attaining the flexibility. It facilitates the combination of high levels of flexibility, high productivity and low level of work- in-process inventory [1]. Flexibility is regarded as an attribute that provides a manufacturing system to withstand a certain level of variations in partial styles without any interruption in production line. When flexibility exists throughout the life cycle of a product, only then system is regarded as a flexible system. The flexibility of the production system can be determined by different tests such as part variety, schedule change, error recovery and new part test. Browne et al. [2] studied various types of flexibilities in his research work. It included routing, machine, operation, production, expansion, process, product and volume. After few years, Sethi and Sethi [3] added material handling, program, and market flexibility criteria to the earlier flexibilities.

The concept of FMS is that it merges the ideology of flow shop and batch shop manufacturing system. Further, it is architecture in such way that the flexibility of job shops is achieved along with accomplishing the effectiveness of dedicated production systems. Also, care must be taken to meet the demands with decreasing time. It is learnt that through FMS, different products with various batch size scans are manufactured simultaneously.

It is learnt from the literature that there are three major components of FMS, i.e., workstations, automated material handling with storage system and a central computer. Workstations are processing stations of FMS, which are involved in performing operations on the part types. For transferring of parts from one station to another, an automated 
material handling system is used, while central computer is used for controlling and coordinating the performance of workstation and material handling system.

\section{DIFFERENT TYPES OF FLEXIBILITIES}

The various forms of flexibilities involved in FMS can be summarized as follows:

- Process flexibility: A particular part produced with different types of process is called Process flexibility.

- Material handling flexibility: The path process employed between machines is the concern.

- Machine flexibility: A single set up is used to perform different operations.

- Operation flexibility: The processing plans vary with respect to production of a part.

- Product flexibility: With the existing product mix, different products are developed.

- Routing flexibility: The achievable routes of the product to be developed are of importance.

- Volume flexibility: Variation in the volume of production.

- Expansion flexibility: Flexibility related to the capacity of production.

- Production flexibility: Without the variation in capital of the equipment, flexibility is achieved for all types of parts.

- Control Program flexibility: Flexibility related to the use of intelligent materials.

\section{Need for Flexible Manufacturing Systems (FMS)}

The flexible manufacturing systems have considered as a boon for many of the production and development industries. The reason behind this can be encapsulated as follows:

- In rapid market changes, the low volume and low production cost can be handled with ease using FMS.

- Increased competition at international platform.

- To achieve improved market response.

- To have flexibility in the production.

- Substantial improvement in the product quality.

- To fulfil customer requirements with ease.

- Reduced production time.

- $\quad$ Reduced cost incurred.

- Reduced labor cost. 


\section{Drawbacks of FMS}

- Expensive.

- Complexity in setup.

- Requirement of skilled labor.

\section{Components of FMS}

Shore et al. [4] categorized few important components of FMS as illustrated below:

- Pallet and Fixtures

- Machining centers

- Inspection equipment

- Chip removal system.

- Storage systems.

- Material handling systems.

\section{MODELING IN FMS: SCHEDULING AND CONTROLLING ISSUES}

The FMS operations are dealt by many researchers. Mainly, they have been classified into mathematical programming approach, multi-criteria decision making approach, Heuristics oriented approach, Control theoretic approach, Simulation based approach and Artificial intelligence (AI) based approach. The prominent outcomes from the literatures dealing with the each technique can be summarized as follows:

\section{Mathematical Programming Approach}

Considering the case of mathematical programming approach, Buzacott and Yao [5] proposed that the analytical methods yield better results than the simulation models. Stecke [6] subdivided the FMS operation preproduction setup and production operation, respectively. They also emphasized on the preproduction setup of the FMS. The complete FMS setup includes Part type selection problem, Machine grouping problem, Production ratio problem, Resource allocation problem and Loading problem. Berrada and Stecke[7] have proposed an efficient branch and bound procedure for solving the loading problem with the objective of workload balancing. Stecke and Solberg [8] recommend unbalancing the workload for each machine when the pooled group sizes are unequal in order to obtain maximum production rate. Lashkariet al. [9] considered re-fixturing and limited tool availability and developed a formulation of the loading problem. The specialty of this technique is it will permit only one allocation of a machine to an operation, which improves the flexibility of the operation control. With a slight modification, a better, simpler and direct formulation was proposed by Wilson [10], Shanker and Rajamarthandan [11]. Han et al. [12] in their model, optimized the number of tools used in the process which facilitates assigning tools and jobs to machines, thereby minimization of tool borrowing can be achieved. With the elapse of time, this mathematical model approach became a topic of research which was dealt and improved by many researchers [13-22]. 


\section{Multi Criteria Decision Making Approach}

Since, it is believed that FMS deals with the process involving multiple criteria, few authors focused on this issue while developing models. Through goal programming, Lee and Jung [23] solved the part selection and allocation problem. It is found that their model can act as a better decision maker with enhanced solution accuracy. For the purpose of providing more number of feasible solutions, Kumar et al. [24] proposed a multi-criteria approach. Analogously, Ro and Kim [25] and O'Grady and Menon [26] discussed the multiple criteria in detail. In recent, Karsak[27] used fuzzy hierarchy process to solve FMS selection problem. Rao [28] incorporated diagraph and matrix method for FMS selection. Rao and Parnichkun [29]; Chatterjee and Chakraborty[30] using FMS selection index matrix, ranked different alternatives of FMS. Further, many methods were modeled to the machine tool utilization [31-35]. Combining Tabu search and simulated annealing method Low et al. [36] resolved FMS scheduling issues.

\section{Heuristics Oriented Approach}

In the above mentioned approach, it was noticed that the use of mathematical computations were cumbersome. This led to the development of Heuristics oriented approach. It generally takes the form of dispatching rules [37-40]. Nofet al. [41] explored different aspects of scheduling and planning. They summarized from their study that the outcome of a problem is directly related to the choices made from other problem. The usage of the dispatching rules was evaluated by Stecke and Solberg [42]. They found that extremely unbalanced loading of the machines caused by the part movement minimization objective gave consistently better performance than balanced loading. The very prominent decision rules to take entire FMS into control were dealt by Iwata et al. [43]. The more research on the dispatching rules can also be found in literature [44-52].

\section{Control Theoretic Approach}

Noticing, the drawbacks of the Heuristics oriented approach, a new control theoretic approach evolved [53]. It also included closed loop formulation (Kimemia and Gershwin [54]; Akellaet al. [55]), discrete time control method (Han and McGinnis [56]). The motto of this control theoretic scheduling policy is to achieve a steady safety buffer of the parts produced in the FMS, as long as it is feasible to do so. A characteristic of the framework is that it is constrained to find a solution within the production capacity of the FMS.

\section{Simulation Approach}

Few pioneers considered a discrete event simulation as a prominent scheduling tool which uses data from actual FMS for simulation Davis and Jones [57]. The scheduling system developed by Jain et al.[58] communicates on-line with the factory control system, generating schedules in real-time. Earlier works on such controlling systems are reported by Wu and Wysk [59], Ishi and Talavage [60]. More recently, Matsui et al. [61] maximized throughput rate of the system and examined the efficiency of the FMS. Further, Potts and Whitehead [62] extended this study for three phase stage. Using Taguchi design, Chan $[63,64]$ evaluated the effect of various parameters such as pallet number, routing levels and dispatching rule on the performance of FMS. A similar study was reported by Ali and Wadhwa [65] to investigate the performance of a flexible system of integrated manufacturing (FSIM) with the aid of analysis of variance (ANOVA) and Taguchi's technique. Caprihan and Wadhwa[66] investigated the effect of information delay on the selection of best routing flexibility levels of FMS. Chan et al [67] studied the direct effect of real time control on the FMS performance. The effect of various routing flexibilities under different aspects of FMS was dealt with Joseph and Sridharan [68], 
Singholi et al. [69-71], Dosdogru et al. [72,] Son and Park [73], Jain and Raj [74], Kumar and Sridharan [75]. The part input sequence was optimized by Cheng and Chan [76] for production planning using simulation models. In multistage production system, Gyulai et al. [77] calculated production plan for assembly lines through simulation method. Similar contributions have also been reported towards developing various simulation models for the accurate evaluation of different aspects of FMS performance [78-83].

\section{Artificial Intelligence Approach}

The problems where human expertise can find reasonable solutions pretty fast, artificial intelligence approach are used. Steffen [84] has presented a survey of AI based scheduling systems. Kusiak and Chen [85] have also reviewed a number of AI-based scheduling approaches. Further research on AI in FMS was carried out by emphasizing much on scheduling production in general [86-90]. Considering if-then rule [91, 92], object-oriented programming [93-95], rule based system [96], nonlinear planning algorithm [97]the process was determined.

\section{BIFURCATION OF FMS}

The previous section deals with the literature survey highlighting the methodological approach used. In this section, the various FMS's are scrutinized and bifurcated based on their complexity. They are

- $\quad$ Dedicated FMS

- $\quad$ Random FMS

- Flexible Assembly Systems

In case of dedicated FMS's, the focus is laid on a few of the pre-selected parts of the system [9, 10, 14, 23, 24, 25, 26, 50, 60, 98, and 99]. However, the random FMS's deals with a broad variety of machine parts [11, 15, 22, 48, 49, 58, 59, 100-103]. Finally, Flexible assembly systems are concerned with more specialized assembly of machine parts.

\section{HURDLES ENCOUNTERED IN FMS}

This section addresses the major issues which are generally faced in the FMS.

\section{Machine Loading}

Machine loading can be defined as a set of tools that are required to produce parts using different resources such as material handling systems, pallets, jigs and fixtures and considers how the parts are assigned so that optimum productivity can be reached [104]. It is related to assigning different jobs to the different machines by taking into consideration the technical constraints and accomplishing the performance. It includes various flexibilities of the process such as operation assignment, part selection, machine capacity, cost, over utilization, etc. The different objectives of machine loading includes the minimization of flow time, inventory and manufacturing costs, re-fixturing stations, tool transport system, makespan, unbalance, tardiness etc. Analogously, maximization of alternate routings, total profit and machine load differences are also considered. Table 1 encapsulates the most prominent researches on the machine loading problem encountered in FMS. 
Table 1: Literatures on Machine Loading Issues in FMS

\begin{tabular}{|l|l|l|}
\hline \multicolumn{1}{|c|}{ Literature } & \multicolumn{1}{|c|}{ Objective } & \multicolumn{1}{c|}{ Findings } \\
\hline $\begin{array}{l}\text { K. E. Stecke\& } \\
\text { F. Brian Talbot }\end{array}$ & $\begin{array}{l}\text { Balancing and unbalancing of } \\
\text { workload }\end{array}$ & $\begin{array}{l}\text { Proposed a method to load tool } \\
\text { magazine in FMS }\end{array}$ \\
\hline $\begin{array}{l}\text { K. Shankar \& } \\
\text { Y. J. Tzen }\end{array}$ & Number of late jobs & $\begin{array}{l}\text { Proposed a computational method } \\
\text { with improved results }\end{array}$ \\
\hline $\begin{array}{l}\text { J. A. Ventura, F. F. Chen, } \\
\text { \& M. S. Leonard }\end{array}$ & Minimization of make span & $\begin{array}{l}\text { The performance of the FMS is } \\
\text { improved }\end{array}$ \\
\hline $\begin{array}{l}\text { B. Ram, S. Sarin, \& } \\
\text { C. S. Chen }\end{array}$ & Maximisation of throughput & The loading time was minimized \\
\hline $\begin{array}{l}\text { S. K. Mukhopadhyay, } \\
\text { S. Midha, \& V. } \\
\text { Murlikrishna }\end{array}$ & Maximisation of throughput & Improved efficiency of FMS \\
\hline $\begin{array}{l}\text { K. Kato, F. Oba, \& F. } \\
\text { Hashimoto }\end{array}$ & Minimization of cutting tools & Algorithm was proved reliable \\
\hline $\begin{array}{l}\text { E. K. Steeke\& F. } \\
\text { Brian Talbot }\end{array}$ & Balancing of workload & Computational efficiency improved \\
\hline $\begin{array}{l}\text { M. K. Tiwari } \\
\text { et al. }\end{array}$ & Minimize system unbalance & $\begin{array}{l}\text { System balance was successfully } \\
\text { achieved }\end{array}$ \\
\hline $\begin{array}{l}\text { G. K. Nayak\& } \\
\text { D. Acharya }\end{array}$ & Maximizing routing flexibility & $\begin{array}{l}\text { Overall system performance has } \\
\text { improved by routing flexibility of } \\
\text { the batches }\end{array}$ \\
\hline $\begin{array}{l}\text { N. Nagarjunaa, } \\
\text { O. Maheshb, \& } \\
\text { K. Rajagopal }\end{array}$ & Minimizing system unbalance & Flexibility of job shops \\
\hline $\begin{array}{l}\text { M. Goswami\& M. } \\
\text { K. Tiwari }\end{array}$ & Maximizing throughput & $\begin{array}{l}\text { Operational decisions are } \\
\text { successfully achieved }\end{array}$ \\
\hline $\begin{array}{l}\text { M. K. Tiwari, J. Saha, } \\
\text { \& S. K. Mukhopadhyay }\end{array}$ & Maximizing throughput & $\begin{array}{l}\text { The approach proposed was efficient } \\
\text { in terms of solution quality }\end{array}$ \\
\hline
\end{tabular}

\section{Layout Design}

In FMS, resolving the issues concerned with layout design is crucial and requires attention at the beginning stage of the process. The role of layout designer is of much importance due to the fact that FMS uses expensive hardware and requires various alternate layouts. A proper design of layout facilitates minimization of transfer time there by increasing the productivity of the unit. In this regard, Kusiak [105] proposed a multilevel decision model. It takes into consideration the issues related to vehicle and machine scheduling. Nayak and Acharya[106] evaluated the problems of continuous facility layout problems. With the aid of composite mutation strategies, Nagarjuna et al. [107] addressed the issues of artificial bee colony. Hajinejad minimized total flow time by developing Particle swarm optimization algorithm. Park et al. [108] aimed at reducing the material handling cost by developing genetic algorithm which optimized the facilities layout with ease.

Since, the better decision with respect to FMS layout can be taken only in combination with the decisions related to the capacity of the workstation, storage units and material handling system, few researches evaluated the dependency of layout design on these factors. Steeke and Talbot [109], Shankar and Tzen.[110] estimated the influence of material handling system on layout design. The effect of storage capacity on layout design was studied in detail by Tiwari et al. [111]. The optimum location of the storage cell in a FMS is studied by Tiwari et al. [112] and Ventura et al. [113]. The problem related to queuing was dealt by Villa et al. [114] and $\mathrm{Wu}$ and Wysk[115]. 


\section{Tool Management}

A major role in FMS is played by tool management. According to Young and Rossi [116], it can be defined as getting the right tool, to the right place and at the right time. The necessity originated from the utilization of high variety and number of cutting tools that are frequently used in automated manufacturing systems. A suitable decision on tool management yields high productivity, thereby increases the profit of the firm. Also, it facilitates efficient part mix and manufacturing quantities. The various features such as tool switching, tool allocation and tool sharing are considered as the integral parts of tool management.

\section{Planning}

The decision or enrouting phase of the automated manufacturing process is known as Planning. The significant subdivisions under this issue include sequencing, scheduling and loading. This phase is concerned with running the FMS by optimally scheduling the flow parts. From the part numbers which are to be processed on the system, subsets are made pertaining to the production orders, requirements from another department in the factory or from a sister plant or customer orders, or maybe forecasted demand. The optimum scheduling can be accomplished by incorporating techniques like Hierarchy method, Heuristic approach [36], Sequence improving procedure and Route exchanging procedure [56], dispatching and knowledge rule [15], break and build model [73], simulation based model [77].

\section{CONCLUSIONS}

In this article, an exhaustive literature survey dealing with the preliminaries of flexible manufacturing system has been carried out. A special has been paid on modelling approaches in FMS, as studied by different pioneers. Also, the literatures dealing with the bifurcation of FMS and various issues concerned in FMS give the reader a brief insight on the actuality of the FMS in industries. It is noticed from the survey that among many modelling techniques, mathematical models are found to be prominent, whereas for evaluating the various system performance, simulation technique proves to be worthy. In addition, with the aid of AI technique, an effective control of FMS can be achieved. This article has made a solemn attempt to highlight the issues and problems related to FMSs, starting from their planning to implementation. However, the exhaustive literature of FMS indicates that still this field has ample room for further research.

\section{REFERENCES}

1. Jang, S. Y., Park, J., \& Park, N. (1996). An integrated decision support system for FMS prod planning and scheduling problems. International Journal Advance Manufacturing Technology, 11, 101-110.

2. Browne, J., Dubois, D., Rathmill, K., Sethi, S. P., and Stecke, K. E., 1984,Classification of flexible manufacturing systems. The FMS Magazine, April1984, 114-1117.

3. Sethi, A. K., and S. P. Sethi. 1990. "Flexibility in Manufacturing: A Survey.” International Journal of Flexible Manufacturing System, Services and Operations Management 2 (4): 289-328.

4. Shore, R. H. and Tompkins, J. A., (2000), Flexible Facilities Design, AIIE Transactions, 12(2), pp 200-205.

5. Buzacott, J. A., and Yao, D. D., 1986, Flexible manufacturing systems: a review of analytical models. Management Science, 32, 890-905.

6. Stecke, K., 1983, Formulation and solution of nonlinear integer production planning problems for flexible manufacturing systems. Management Science, 29,273-288. 
7. Berrada, M., and Stecke, K. E., 1986, A branch and bound approach for machine load balancing in flexible manufacturing systems. Management Science, 32, 1316-1335.

8. Stecke, K. E., and Solberg, J. J., 1982, The optimality of unbalanced workloads and machine group sizes for flexible manufacturing system. Working Paper No. 290, Graduate School of Business Administration, The University of Michigan, Ann Arbor, Michigan.

9. Lashkari, R. S., Dutta, S. P., and Padhye, A. M., 1987, A new formulation of operation allocation problem in flexible manufacturing systems: mathematical modelling and computational experience. International Journal of Production Research, 25, 1267-1283.

10. Wilson, J. M., 1989, An alternative formulation of the operation-allocation problem in flexible manufacturing systems. International Journal of Production Research, 27, 1405-1412.

11. Shanker, K., and Rajamarthandan, S., 1989, Loading problem in FMS: part movement minimization. Proceedings of the Third ORSA/TIMS Conference on Flexible Manufacturing Systems. 99-104.

12. Han, M., Na, Y. K., and Hogg, G. L., 1989, Real-time tool control and job dispatching in flexible manufacturing systems. International Journal of Production Research, 27, 1257-1267.

13. Kimemia, J., and Gershwin, S. B., 1985, Flow optimization in flexible manufacturing systems. International Journal of Production Research, 23, 81- 96.

14. Chen, I. J., and Chung, C. H., 1991, Effects of loading and routeing decisions on performance of flexible manufacturing systems. International Journal of Production Research, 29, 2209-2225.

15. Hutchison, J., Leong, K., Snyder, D., and Ward, F., 1989, Scheduling for random job shop flexible manufacturing systems. Proceedings of the Third ORSA/TIMS Conference on Flexible Manufacturing Systems, 161-166.

16. Shanker, K., and Tzen, Y. J., 1985, A Loading and dispatching problem in a random flexible manufacturing system. International Journal of Production Research, 23, 579-595

17. Stecke, K. E. and Talbot, F. B. (1983) Heuristic Loading Algorithms for Flexible Manufacturing Systems. Proceedings of the Seventh International Conference on Production Research, Windsor, 22-24 August 1983.

18. Shanker, K., and Srinivasulu, A., 1989, Some methodologies for loading problems in flexible manufacturing systems. International Journal of Production Research, 27, 1019-1034.

19. Hwan, S. S., and Shogun, A. W., 1989, Modelling and solving an FMS part selection problem. International Journal of Production Research, 27, 1349- 1366.

20. Sarin, S. C., and Chen, C. S., 1987, The machine loading and tool allocation problem in a flexible manufacturing system. International Journal of Production Research, 25, 1081-1094.

21. Ram, B., Sarin, S. and Chen, C. S. (1990) A Model and Solution Approach for the Machine Loading and Tool Allocation Problem in FMS. International Journal of Production Research, 28, 637-645.

22. Co, H. C., Biermann, J. S., and Chen, S. K., 1990, A methodical approach to the flexible manufacturing system batching, loading, and tool configuration problems. International Journal of Production Research, 28, 2171-2186.

23. Lee, S. M., and Jung, H., 1989, A multi-objective production planning model in a flexible manufacturing environment. International Journal of Production Research, 27, 1981-1992. 
24. Kumar, P., Tewari, N. K., and Singh, N., 1990, Joint consideration of grouping and loading problems in a flexible manufacturing system. International Journal of Production Research, 28, 1345-1346.

25. Ro, I. K., and Kim, J. I., 1990, Multi-criteria operational control rules in flexible manufacturing systems (FMSs). International Journal of Production Research,28, 47-63.

26. O'Grady, P. J., and Menon, U., 1987, Loading a flexible manufacturing system. International Journal of Production Research, 25, 1053-1068.

27. Karsak, E. E. 2002. “Distance-Based Fuzzy MCDM Approach for Evaluating Flexible Manufacturing System Alternatives." International Journal of Production Research 40 (13): 3176-3181.

28. Rao, R. V. 2008. "Evaluating Flexible Manufacturing System Using a Combined Multiple Attribute Decision Making Method.” International Journal of Production Research 46 (7): 1975-1989.

29. Rao, R. V., and M. Parnichkun. 2009. "Flexible Manufacturing System Selection Using a Combinatorial Mathematics Based Decision Making Method.” International Journal of Production Research 47 (24): 6981-6998.

30. Chatterjee, P., and S. Chakraborty. 2014. "FMS Selection Using Preference Ranking Method: A Comparative Study." International Journal of Industrial Engineering Computations 5: 315-338.

31. Yurdakul, M. 2004. “AHP as a Strategic Decision Making Tool to Justify Machine Tool Selection.” Journals of Materials Processing Technology 146 (3): 365-376.

32. Ayag, Z., and R. G. Ozdemir. 2006. “A fuzzy AHP approach to evaluating machine tool alternatives.” International Journal of Intelligent Manufacturing 17 (2): 179-190.

33. Taha, T., and S. Rostam. 2012. "A Hybrid Fuzzy AHP-PROMETHEE Decision Support System for Machine Tool Selection in Flexible Manufacturing Cell.” Journal of Intelligent Manufacturing 23: 2137-2149.

34. Buyurgan, N., C. Saygin, and S. E. Killic. 2004. "Tool Allocation in Flexible Manufacturing System with Tool Alternatives."Robotics and Computer Integrated Manufacturing 20: 341-349.

35. Jayamohan, M. S., and C. Rajendran. 2004. "Development and Analysis of Cost-Based Dispatching Rules for Job Shop Scheduling. ” European Journal of Operational Research 157 (2): 307-321.

36. Low, C., Y. Yip, and T. H. Wu. 2006. "Modelling and Heuristics of FMS Scheduling with Multiple Objectives.” Computers and Operations Research 33: 674-694.

37. Conway, R. W., 1965, Priority dispatching and work in process inventory in a job shop. Journal of Industrial Engineering, 16, 123-130.

38. Conway, R. W., 1965b, Priority dispatching and job lateness in a job shop. Journal of Industrial Engineering, 16, $228-237$.

39. Panwalker, S. S., and Iskander, W., 1977, A survey of scheduling rules. Operations Research, 25, 45-61.

40. Gere, W. S., 1966, Heuristics in job shop scheduling. Management Science, 13, 167-190.

41. Nof, S. Y., Barash, M. M., and Solberg, J. J., 1979, Operational control of item flow in versatile manufacturing systems. International Journal of Production Research, 17, 479-489.

42. Stecke, K. E., and Solberg, J. J., 1981, Loading and control policies for a flexible manufacturing system. International Journal of Production Research, 19, 481-490. 
43. Iwata, K., Murotsu, A., Oba, F., and Yasuda, K., 1982, Production scheduling of flexible manufacturing systems. Annals of the CIRP, 31, 319-322.

44. Montazeri, M., and Van Wassenhove, L. N., 1990, Analysis of scheduling rules for an FMS. International Journal of Production Research, 28, 785-802.

45. Buzacott, J. A., and Shanthikumar, J. G., 1980, Models for understanding flexible manufacturing systems. AIIE Transactions, 12, 339-349.

46. Buzacott, J. A., 1982, Optimal operating rules for automated manufacturing systems. IEEE Transactions on Automatic Control, AC-27, 80-86.

47. Moreno, A. A., and Ding, F., 1989, Goal oriented heuristics for the FMS loading (and part type selection) problems. Proceedings of the Third ORSA/TIMS Conference on Flexible Manufacturing Systems, 105-110.

48. Chang, Y., Matsuo, H., and Sullivan, R. S., 1989, A bottleneck-based beam search for job scheduling in a flexible manufacturing system. International Journal of Production Research, 27, 1949-1961.

49. Chang, Y., and Sullivan, R. S., 1990, Schedule generation in a dynamic job shop. International Journal of Production Research, 28, 65-74.

50. Slomp, J., Gaalman, G. J. C., and Nawijin, W. M., 1988, Quasi on-line scheduling procedures for flexible manufacturing systems. International Journal of Production Research, 26, 585-598.

51. Choi, R. H., and Malstrom, E. M., 1988, Evaluation of traditional work scheduling rules in a flexible manufacturing system with a physical simulator. Journal of Manufacturing Systems, 7, 33-45.

52. Wilhelm, W. E., and Shin, H. M., 1985, Effectiveness of alternate operations in a flexible manufacturing systems. International Journal of Production Research,23, 65-79.

53. Gershwin, S. B., 1989, Hierarchical flow control: a framework for scheduling and planning discrete events in manufacturing systems. Proceedings of the IEEE, 77, 195-209.

54. Kimemia, J. G., and Gershwin, S. B., 1983, An algorithm for the computer control of production in flexible manufacturing systems. IIE Transactions, 15, 353- 362.

55. Akella, R., Choong, Y., and Gershwin, S. B., 1984, Performance of hierarchical production scheduling policy. IEEE Transactions on Components, Hybrids, and Manufacturing Technology, CHMT-7, 215-217.

56. Han, M. H., and McGinnis, L. F., 1989, Flow control in flexible manufacturing: minimization of stock out cost. International Journal of Production Research,27, 701-715.

57. Davis, W. J., and Jones, A. T., 1989, On-line concurrent simulation in production scheduling. Proceedings of the Third ORSA/TIMS Conference on Flexible Manufacturing Systems, 253-258.

58. Jain, S., Barber, K., and Osterfeld, D., 1990, Expert simulation for on-line scheduling. Proceedings of the 1989 Winter Simulation Conference, 930-935.

59. Wu, S. D., and Wysk, R. A., 1989, An application of discrete-event simulation toon-line control and scheduling in flexible manufacturing. International Journal of Production Research, 27, 1603-1623.

60. Ishi, N., and Talavage, J. J., 1991, A transient-based real-Time scheduling algorithm in FMS. International Journal of Production Research, 29, $2501-2520$. 
61. Matsui, M., S. Uehara, and M. Jingsong. 2001. "Performance Evaluation of Flexible Manufacturing Systems with Finite Local Buffers: Fixed and Dynamic Routings.” International Journal of Flexible Manufacturing Systems 13: 405-424.

62. Potts, C. N., and J. D. Whitehead. 2001. "Workload Balancing and Loop Layout in the Design of a Flexible Manufacturing System." European Journal of Operational Research 129: 326-336.

63. Chan, F. T. S. 2001. "The Effects of Routing Flexibility on a Flexible Manufacturing System." International Journal of Computer Integrated Manufacturing 14 (5): 431-445.

64. Chan, F. T. S. 2003. "Effects of Dispatching and Routeing Decisions on the Performance of a Flexible Manufacturing System.” International Journal of Advance Manufacturing Technology 21: 328-338.

65. Ali, M., and S. Wadhwa. 2010. "The Effect of Routing Flexibility on a Flexible System of Integrated Manufacturing." International Journal of Production Research 48 (19): 5691-5709. doi:10.1080/00207540903100044

66. Caprihan, R., and S. Wadhwa. 2005. "Scheduling of FMS with Information Delays: A Simulation Study.” International Journal of Flexible Manufacturing System 17: 39-65.

67. Chan, F. T. S., R. Bhagwat, and S. Wadhwa. 2008. "Comparative Performance Analysis of a Flexible Manufacturing System (FMS): A Review Period Based Control.” International Journal of Production Research 46 (1): 1-24.

68. Joseph, O. A., and R. Sridharan. 2011. "Evaluation of Routing Flexibility of a Flexible Manufacturing System Using Simulation Modelling and Analysis.” International Journal of Advance Manufacturing Technology 56: 273-289.

69. Singholi, A. 2015. "Impact of Manufacturing Flexibility and Pallets on Buffer Delay in Flexible Manufacturing Systems." International Journal of Engineering Management and Economics 5 (3-4): 308-330.

70. Singholi, A., D. Chhabra, and M. Ali. 2010. "Towards Improving the Performance of Flexible Manufacturing System: A Case Study.” Journal of Industrial Engineering and Management 3 (1): 87-115.

71. Singholi, A., M. Ali, and C. Sharma. 2013. "Evaluating the Effect of Machine and Routing Flexibility on Flexible Manufacturing System Performance." International Journal of Services and Operations Management 16 (2): $240-261$.

72. Dosdogru, A. T., M. Gocken, and F. Geyik. 2015. "Integration of Genetic Algorithm and Monte Carlo to Analyze the Effect of Routing Flexibility.” International Journal of Advanced Manufacturing Technology 81: 1379-1389.

73. Son, Y. K., and C. S. Park. 1990. "Quantifying Opportunity Costs Associated with Adding Manufacturing Flexibility." International Journal of Production Research 28: 1183-1194.

74. Jain, V., and T. Raj. 2016. "Modeling and Analysis of FMS Performance Variables by ISM, SEM and GTMA Approach." International Journal of Production Economics 171: 84-96.

75. Kumar, N. S., and R. Sridharan. 2009. "Simulation Modeling and Analysis of Part and Tool Flow Control Decisions in Flexible Manufacturing System.” International Journal of Robotics and Computer Integrated Manufacturing 25: 829-838.

76. Cheng, H. C., and D. Y. K. Chan. 2011. "Simulation Optimization of Part Input Sequence in a Flexible Manufacturing System." Proceedings of the Winter Simulation Conference, Phoenix, AZ, December 11-14, 2374-2382.

77. Gyulai, D., A. Pfeiffer, and L. Monostori. 2016. "Robust Production Planning and Control for Multi-Stage Systems with Flexible Final Assembly Lines.” International Journal of Production Research 55 (13): 3657-3673. doi:10.1080/ 00207543.2016 .1198506$.

78. Yang, Y., Y. Chen, and C. Long. 2016. “Flexible Robotic Manufacturing Cell Scheduling Problem with Multiple Robots.” International Journal of Production Research 54 (22): 6768-6781. doi:10.1080/00207543.2016.1176267. 
79. Gingu, E. I., and M. Zapciu. 2014. "Improving Layout and Workload of Manufacturing System Using Delmia Quest Simulation and Inventory Approach.” International Journal of Innovative Research in Advanced Engineering 1 (6): 52 61.

80. Arshad, M., M. Milana, and M. K. Khan. 2016. "Scheduling of Three Layouts Using Four Scheduling Rules." ProceedingsInternational Conference on Industrial Engineering and Operations Management, Kula Lumpur, March 8-10, 2539-2548.

81. Rybicka, J., A. Tiwari, and S. Enticott. 2016. "Testing a Flexible Manufacturing System Facility Production Capacity through Discrete Event Simulation: Automotive Case Study." International Journal of Mechanical, Aerospace, Industrial, Mechatronics and Manufacturing Engineering 10 (4): 668-672.

82. Florescu, A., S. Baarabas, and F. Sarbu. 2017. “Operational Parameters Estimation for a Flexible Manufacturing System: A Case Study." MATEC Web of Conference 112: 1-6.

83. Surendrakumar S. Nagpure \& M. S. Tufail, Concept of Automated Machining and Inspection in FMS, International Journal of Mechanical and Production Engineering Research and Development (IJMPERD), Volume 4, Issue 2, March - Apri 2014, pp. $9-20$

84. Mahmood, K., T. Karaulova, T. Otto, and E. Shevtshenko. 2017. "Performance Analysis of a Flexible Manufacturing System Performance." The 50th CIRP Conference on Manufacturing Systems, Procedia CIRP-63, May 3-5, Taichung City, Taiwan, 424-429.

85. Steffen, M. S., 1986, A survey of artificial intelligence-based scheduling systems. Proceedings, Fall Industrial Engineering Conference, Institute of Industrial Engineers, Norcross, Georgia.

86. Kusiak, A., and Chen, M., 1988, Expert systems for planning and scheduling manufacturing systems. European Journal of Operational Research, 34, 113- 130.

87. Bullers, W. I., Nof, S. Y., and Whinston, A. B., 1980, Artificial intelligence in manufacturing planning and control. AIIE Transactions, 12, 351-363.

88. Fox, M. S., Allen, B., and Strohm, G., 1982, Job-shop scheduling: an investigation in constraint-directed reasoning. Proceedings of the National Conference on Artificial Intelligence, 155-158.

89. Bourne, D. A., and Fox, M. S., 1984, Autonomous manufacturing: automating the job-shop. IEEE Computer, 17, 76-86.

90. Bensana, E., Bel, G., and Dubois, D., 1988, OPAL: A multi-knowledge-based system for industrial job-shop scheduling. International Journal of Production Research, 26, 795-819.

91. Chiodini, V., 1986, A knowledge based system for dynamic manufacturing replanning. Symposium on Real-Time Optimization in Automated Manufacturing Facilities, National Bureau of Standards, Gaithesburg, Maryland.

92. Hall, M. D., and Putnam, G., 1984, An application of expert systems in FMS. Auto fact 6, Society of Manufacturing Engineers.

93. Kusiak, A., 1986, FMS scheduling: a crucial element in an expert system control architecture. IEEE 1986 International Conference on Robotics and Automation, 653-658.

94. Sauve, B., and Collinot, A., 1987, An expert system for scheduling in a flexible manufacturing system. Robotics and ComputerIntegrated Manufacturing, 3, 229-233.

95. Maley, J. G., Ruiz-Meir, S., and Solberg, J. J., 1988, Dynamic control in automated manufacturing: a knowledge integrated approach. International Journal of Production Research, 26, 1739-1748.

96. Bu-Hulaiga, M. I., and Chakravarty, A. K., 1988, An object-oriented knowledge re presentation for hierarchical real-time control of flexible manufacturing. International Journal of Production Research, 26, 821-844. 
97. Bruno, G., Elia, A., and Laface, P., 1986, A rule-based system to schedule reproduction. IEEE Computer, 19, 32-40.

98. Shaw, M. J., 1988, Knowledge-based scheduling in flexible manufacturing systems: an integration of pattern-directed interference and heuristic search. International Journal of Production Research, 26, 821-844.

99. Avonts, L. H. and Wassenhove, L. N., 1988, The part mix and routing mix problem in FMS: a coupling between an LP model and a closed queuing network. International Journal of Production Research, 26, 1891-1902.

100. Ram, B., Sarin, S. C., and Chen, C. S., 1987, A model and a solution approach for the machine loading and tool allocation problem in a flexible manufacturing system. International Journal of Production Research, 28, 637-645.

101. Mukhopadhyay, S. K., Midha, S. and Murlikrishna, V. (1992) A Heuristic Procedure for Loading Problem in Flexible Manufacturing Systems. International Journal of Production Research, 30, 2213-2228.

102. Chandra, J., and Talavage, J., 1991, Intelligent dispatching for flexible manufacturing. International Journal of Production Research, 29, 2259-2278.

103. Sabuncuoglu, I., and Hommertzheim, D. L., 1989, Expert simulation systems - recent developments and applications in flexible manufacturing systems. Computers in Industrial Engineering, 16, 575-585.

104. Sabuncuoglu, I., and Hommertzheim, D. L., 1992, Experimental investigation of FMS machine and AGV scheduling rules against the mean flow-time criterion. International Journal of Production Research, 30, 1617-1635.

105. Kato, K., Oba, F. and Hashimoto, F. (1993) Loading and Batch Formation in Flexible Manufacturing Systems. Control Engineering Practice, 1, 845-850.

106. Kusiak, A., 1985, Flexible manufacturing systems: a structured approach. International Journal of Production Research, 23, 1057-1073.

107. Nayak, G. K. and Acharya, A. D. (1998) Part Type Selection, Machine Loading and Part Type Volume Determination in FMS Planning. International Journal of Production Research, 36, 1801-1824.

108. Nagarjuna, N., Mahesh, O. and Rajagopal, K. (2006) A Heuristic Based on Multi-Stage Programming Approach for MachineLoading Problem in a Flexible Manufacturing System. Robotics and Computer-Integrated Manufacturing, 22,342-352.

109. Park, S. C., Raman, N., and Shaw, M. J., 1989, Heuristic learning for pattern directed scheduling in a flexible manufacturing system. Proceedings of the Third ORSA/TIMS Conference on Flexible Manufacturing Systems, 369-376.

110. Steeke, E. K. and Talbot, F. B. (1995) Heuristics for Loading Flexible Manufacturing Systems, Flexible Manufacturing Systems: Recent Developments. Elsevier Science B. V., Amsterdam, 171-176.

111. Shankar, K. and Tzen, Y. J. J. (1985) A Loading and Dispatching Problem in a Random Flexible Manufacturing System. International Journal of Production Research, 23, 579-595.

112. Tiwari, M. K., Saha, J. and Mukhopadhyay, S. K. (2007) Heuristic Solution Approaches for Combined-Job Sequencing and Machine Loading Problem in Flexible Manufacturing Systems. International Journal of Advanced Manufacturing Technology, 31, 716-730.

113. Tiwari, M. K., Hazarika, B., Vidyarthi, N. K., Jaggi, P. and Mukhopadhyay, S. K. (1997) A Heuristic Solution Approach to the Machine Loading Problem of FMS and Its Petri Net Model. International Journal of Production Research, 35, 2269-2284.

114. Ventura, J. A., Chen, F. F. and Leonard, M. S. (1988) Loading Tools to Machines in Flexible Manufacturing Systems. Computers \& Industrial Engineering, 15, 223-230. 
115. Villa, A., Mosca, R., and Murari, G., 1986, Expert control theory: a key for solving production planning and control problems in flexible manufacturing. IEEE 1986 International Conference on Robotics and Automation, 466-471.

116. Wu, S. D., and Wysk, R. A., 1988, Multi-pass expert control system - a control/scheduling structure for flexible manufacturing cells. Journal of Manufacturing Systems, 7, 107-120.

117. Young, R. E., and Rossi, M. A., 1988, Toward knowledge-based control of flexible manufacturing systems. IIE Transactions, 20, 36-43. 